Environment Conservation Journal 14(1\&2) 55-59, 2013

ISSN 0972-3099 (Print) 2278-5124 (Online)

Abstracted and Indexed

\title{
Morphometric analysis of freshwater crab, Potamon koolooense (Decapoda: Brachyura: Potamidae) from hillstream Khoh, Uttarakhand
}

\author{
Shurveer Singh ${ }^{1}$, Ashish K. Chowdhary ${ }^{1}$, Anita Rawat Rana ${ }^{2}$ and S.N. Bahuguna $\varpi^{1}$
}

Received: 11.10.2012

Accepted: 13.02.2013

\begin{abstract}
The present study was carried out on freshwater crab in hillstream Khoh of district Pauri Garhwal in Uttarakhand state. Samples of crab were collected from the population inhabits the hillstream Khoh on monthly basis during May 2011 to April 2012. The regression equations for the length-weight relationship in crabs were obtained as $Y=2.045 X+0.266$ and $Y=1.522 X+0.392$ for males and females respectively. The ANOVA test revealed significant differences in carapace lengthweight relationship at $\mathbf{p}<\mathbf{0 . 0 5}$ for both the sexes. Allometric growth pattern was observed in the study for both sexes of $P$. koolooense. A weak relationship was observed between length and weight of the specimen.
\end{abstract}

Keywords ANOVA, Freshwater crab, Hillstream Khoh, Length-weight relationship, Potamon koolooense

\section{Introduction}

Uttarakhand state located in Western Himalaya and bestowed with diversified flora and fauna, sustains large number of fish species, invertebrates, macro invertebrates and insects due to varied freshwater aquatic environment. Freshwater crabs also comprise a considerable part of that aquatic biodiversity. These complete their life cycles independent of marine environments, as is conventionally thought off and also have different reproductive strategies from most marine crabs. Because of their high abundance and biomass, freshwater crabs are important members of limnetic environments, where they play an important role in the trophic web, acting in nutrient cycling (Goulding et al. 1988, Hill \& O’Keeffe 1992, Dobson et al. 2007). Their use as human food was reported by (Magalhães et al., 2006), and their economic and medical importance was well documented by (Yeo et al., 2008). Information about individual body weight-length/width relationships in populations is important for estimating the population size of a stock, specifically for the purpose of its

\section{Author's Address}

${ }^{1}$ Department of Zoology and Biotechnology, P.B.70, HNB Garhwal University Srinagar Garhwal-246 174, Uttarakhand, ${ }^{2}$ Department of Zoology, Govt. P.G. College, Rishikesh, Email: profsnbahuguna@rediffmail.com exploitation. In crustaceans, as growth progresses, certain dimensions of the animal's body may grow much more than others, resulting in the phenomenon known as relative growth, (Hartnoll, 1974).According to Lagler, (1968), the relationship can be used to estimate the recovery of edible meat from crabs of various sizes. Relatively less information is available on hillstream crustacean fisheries i.e. crabs, prawn in Uttarakhand. Several workers have been made good contribution in morphometric study eg. length-weight characteristics of crabs by (Sukumaran et al. 1997, Prasad et al. 1989, Oriola et al. 2005, and Abowei and George, 2010). Therefore, present study deals with important morphological characters of the specimen and relationship between them, which would be a plate form for further studies on the specimen in future.

\section{Material and Methods}

The study area falls in Pauri Garhwal district of Uttarakhand that lies between $25^{\circ} 45^{\prime}$ to $30^{\circ} 15^{\prime}$ latitude and $78^{\circ} 24^{\prime} \mathrm{N}$ to $79^{\circ} 23^{\prime} \mathrm{E}$ longitude (Fig. 1). The samples of $P$. koolooense were collected monthly by hand picking from hill stream Khoh by turning out the roots of marginal plants, under the stones and from sandy bottom of the stream. 
Fig. 1: Map showing the study area in Uttarakhand

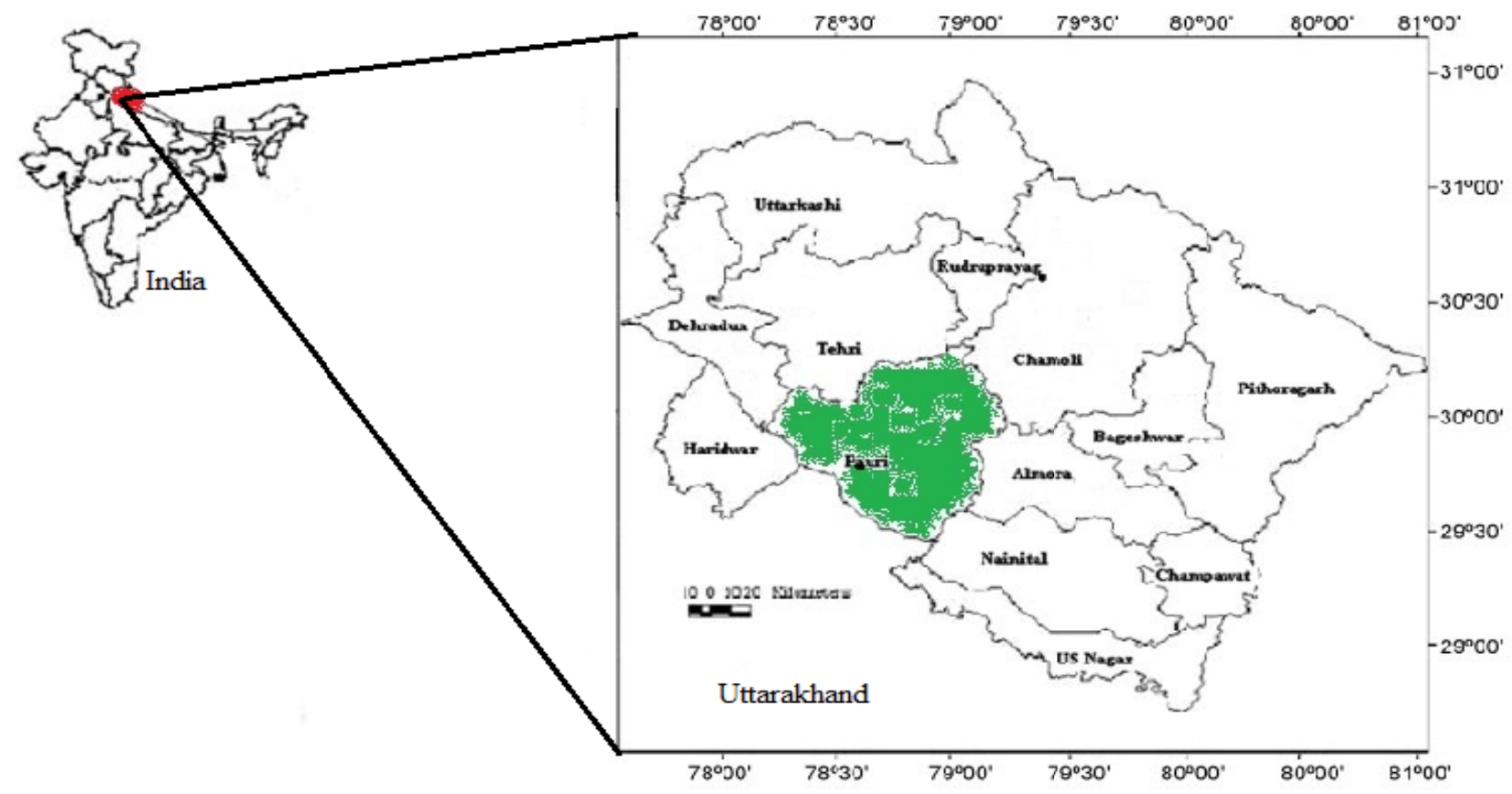

Sampling always took place during the day time in $50 \mathrm{~m}$ stretch along the length of stream for two hours from the selected sites. Total 228 crabs were collected during study period 2011-2012 from the study area and differentiated into 106 females and 122 males by observing the shape of their abdomens. All collected specimens were preserved in $8 \%$ formalin in laboratory for further studies. To examine growth, carapace length of the specimens were taken to nearest $0.1 \mathrm{~cm}$ with the help of slide vernier caliper and weight of crab nearest to $0.1 \mathrm{~g}$ was taken by digital weighing balance, A named Mx7000 series. The length-weight relationship is usually represented by the equation- $\mathbf{W}=\mathbf{a} \mathbf{L}^{\mathbf{b}}$

Where,

' $\mathrm{W}$ ' is the total body weight of crab in gram and ' $\mathrm{L}$ ' is the carapace length of crab in cm. ' $a$ ' and ' $b$ ' are intercept and slope respectively. Value of 'a' and 'b' was estimated by linear regression analysis from logarithmically transformed data. Regression equation was obtained by processed the collected data on length-weight in computer. ANOVA was used to test the significant difference of lengthweight relationship in crab by using F- test. Student t-test was calculated to determine the growth pattern in the crab by comparing the two slope value for possible significant differences between the sexes.

\section{Results and Discussion}

In the present study 228 crabs, 122 males and 106 females were sampled belonging to family potamidae under the order decapoda section brachyura. Samples of crab were identified as Potamon koolooense by using standard keys to family potamidae and from existing literature. Color of the crab show variations from purplish with black patches on the whole body in juvenile stage to dark or reddish brown in the adult stage. Males were more in number than females. Chelipeds are unequal in both the sexes. The carapace length was ranged from $1.2 \mathrm{~cm}$ to $5.9 \mathrm{~cm}$ for male and female crabs. And the weight was ranged from $1.08 \mathrm{gm}$ to $65.62 \mathrm{gm}$. From the processed data regression equation for the lengthweight relationship obtained were as follows:

Male

$$
\begin{array}{rlrl}
\text { Female } Y & =2.045 X+0.226, & & r^{2}=0.417 \\
Y & =1.522 X+0.392, & r^{2}=0.301
\end{array}
$$

(Fig. 2 and 3) 
Value of slope 'b' calculated for male was 2.045 and for female was 1.522, showed allometric growth in the respective sex (Table 1).

The ANOVA using F-test revealed a significant difference between carapace length-weight relationship in crabs at $(\mathrm{p}<0.05)$ for the different sexes shown in (Table $2 \& 3$ ). The coefficient of determination obtained for male $r^{2}=0.417$ and for female $r^{2}=0.301$ indicating a weak positive correlation between length and weight parameters involved in the relationship. The regression lines obtained from logarithm of weight on logarithm of length of $P$. koolooense were observed straight showed a good relationship between length and weight of the crab (Fig. 2 and 3). Analysis of variance using F-test revealed significant differences between the two sex at $\mathrm{P}>0.05$. Student t-test indicated the allometric growth pattern in $P$. koolooense shown in (Table 1).

Fig. 2: Length-Weight Relationship in male P. koolooense

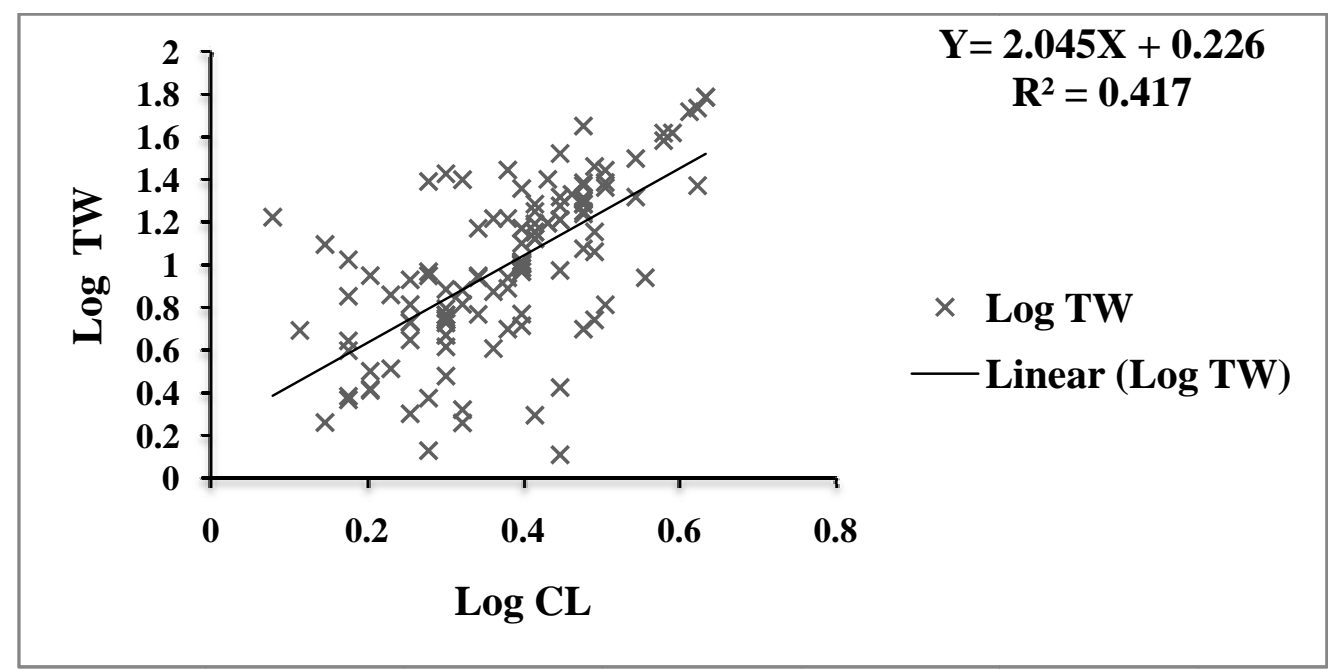

Fig. 3: Length-Weight Relationship in female $P$. koolooense

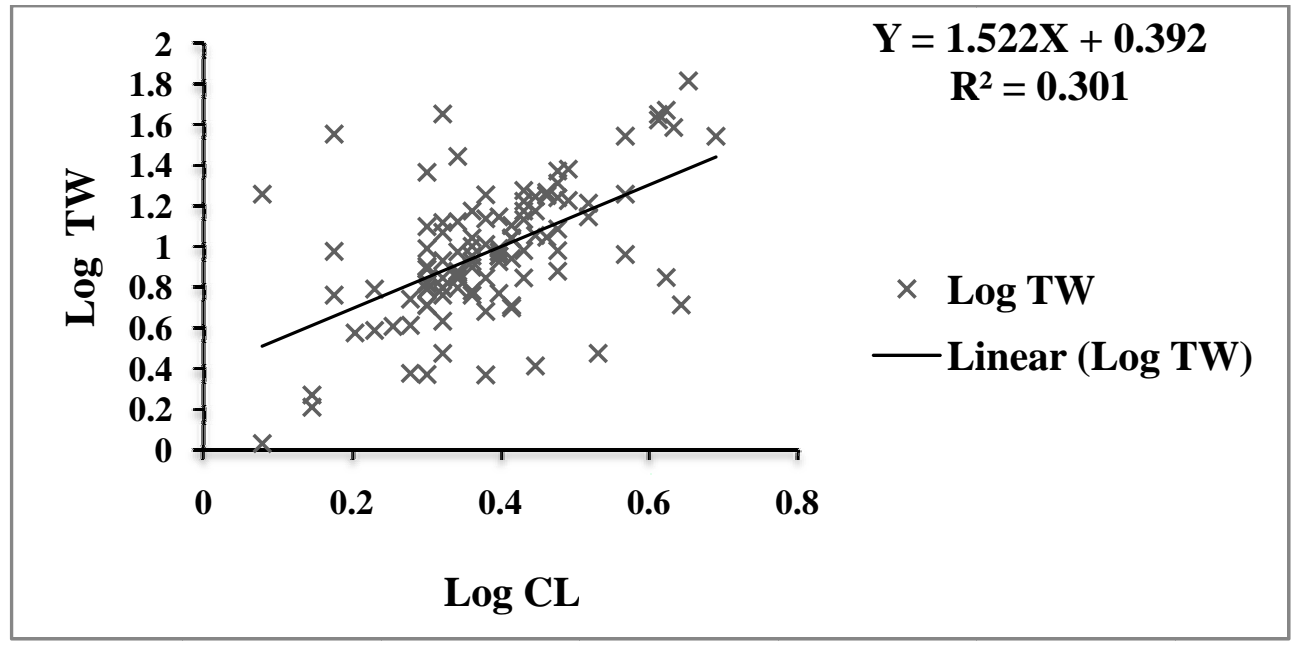


Table 1: Regression statistics between length and weight and t-test to show growth pattern in P. koolooense

\begin{tabular}{|l|l|l|l|l|l|l|}
\hline Sex & No. & Slope & Intercept & $\mathbf{r}^{2}$ & $\mathbf{t}(\mathbf{0 . 0 5})$ & $\begin{array}{l}\text { Growth } \\
\text { pattern }\end{array}$ \\
\hline Male & 122 & 2.045 & 0.226 & 0.417 & 9.278938 & Allometric \\
\hline Female & 106 & 1.522 & 0.392 & 0.301 & 6.691434 & Allometric \\
\hline
\end{tabular}

Table 2: ANOVA to test significant difference between length \& weight relationship in male $P$. koolooense

\begin{tabular}{|l|l|l|l|l|l|}
\hline ANOVA & & & & & \\
\hline & Df & SS & MS & F & Significance F \\
\hline Regression & 1 & 7.208774 & 7.208774 & 86.09869 & $8.96 \mathrm{E}-16$ \\
\hline Residual & 120 & 10.04722 & 0.083727 & & \\
\hline Total & 121 & 17.256 & & & \\
\hline
\end{tabular}

Table 3: ANOVA to test significant difference between length \& weight relationship in female $P$. koolooense

\begin{tabular}{|l|l|l|l|l|l|}
\hline ANOVA & & & & & \\
\hline & $d f$ & SS & MS & F & Significance $F$ \\
\hline Regression & 1 & 3.490815 & 3.490815 & 44.77529 & $1.14 \mathrm{E}-09$ \\
\hline Residual & 104 & 8.108149 & 0.077963 & & \\
\hline Total & 105 & 11.59896 & & & \\
\hline
\end{tabular}

\section{Acknowledgement}

Thanks to UGC, New Delhi for providing Rajeev Gandhi National Fellowship to Shurveer Singh for conducting the research work.

\section{References}

Abowei, J. F. N. and George, A. D. I. 2010. The Morphology, Size and Sex Distribution of Callinectes amnicola (De Rochebrune, 1883) from Okpoka Creek, Niger Delta, Nigeria. Current Research Journal of Biological Sciences 2 (1): 27-34.

Dobson, M. K., Magana, A. M., Lancaster, J. and Mathooko, J. M. 2007. Seasonality in the abundance and life history of an ecologically dominant freshwater crab in the Rift Valley, Kenya. Freshwater Biology, 52: 215-225.

Dulcic, J. and Kraljevic, M. 1996. Weight- length relationship for 40 fish species the Adriatic (Crotian Waters). Fish. Res., 28: 23-251.

Gokce, G., Eeguden, D., Sangun, L., Cekic, M. and Alagoz, S. 2006. Width/length-weight and relationships of the blue crab (Callinectes sapidus, Rathbun, 1986) population living in

Camlik Lagoon Lake (Yamurtalik). Pak. J. Biol. Sci., 9 (8): 14601464.

Goulding, M. G., Carvalho, M. L. and Ferreira, E. G. 1988 (Eds.). Rio Negro, rich life in poor water. Amazonian diversity and food chain ecology as seen through fish communities. The Hague, SPB Academic, 200p.

Hartnoll, R. G. 1974. Variation in growth pattern between some secondary sexual characters in crabs (Decapoda, Brachyura). Crustaceana, 27: 131-136.

Hill, M. P. and O. Keeffe, J. H. 1992. Some aspects of the ecology of the freshwater crab (Potamonautes perlatus Milne Edwards) in the upper reaches of the Buffalo River, eastern Cape Province, South Africa. South African Journal of Aquatic Sciences, 18: 42-50.

Jones, R. E., Petrell, R. J. and Pauly, D. 1999. Using modified length-weight relationship to assess the condition of fish. Aquaticultural Eng., 20 (40): 261-276.

Lagler, K. F. 1968. Capture, Sampling and Examination of Fishes. In W. E. Ricker (ed). Methods for Assessment of Fish Production in Freshwaters. IBP, Handbook III. P. 7-45.

Magalhães, C., Barbosa, U. C. and Py-Daniel, V. 2006. Decapod crustaceans used as food by the Yanomami Indians of the Balawa-ú village, State of Amazonas, Brazil. Acta Amazônica, 35(3): 369-374.

Moutopoulos, D. K. and Stergiou, K. I. 2002. Weight-length and length-length relationships for 40 fish species of the Eagen Sea (Hellas). J. Applies Icthyol., 18: 200-203. DOI: 10.1046/j. 1439-0426.2002. 00338. X. 
Olusoji Bello, O. A., Anifowose, O. J. and Sodamola, M. Y. 2009. Length-Weight Relationships, Condition Factor and Fecundity of the West Africa Freshwater Crab, Sudanonautes africanus (Milne- Edwards 1883) in Western Nigeria. West African Journal of Applied Ecology, Vol. 16 65-74.

Oriola, A. O., Anetekhai, M. and Olowonirejuaro, K. 2005. Morphometric and Meristic Studies in Two Crabs: Cardisoma armatum and Callinectes pallidus. Turkish Journal of Fisheries and Aquatic Sciences 5:85-89.

Prasad, P. N., Reeoy, J., Kusuma, N. and Neelakantan, B. 1989. Width-Weight and Length-Weight Relationships in Three Portunid Crab species Uttar Pradesh. J. Zool., 9: 116-120.
Sukumaran, K. K. and Neelakantan B. 1997. Length-Weight Relationship in Two Marine Portunid Crabs Portunus sanguinolentus (Herbst) and Portunus pelagicus (Linnaeus) from Karnataka Coast. Indian J. Mar. Sci. 26: 39-42.

Yeo, D. J. C., Ng, P. K. L., Cumberlidge, N., Magalhães, C., Daniels, S. R. and Campos, M. R. 2008. Global diversity of crabs (Crustacea: Decapoda: Brachyura) in freshwater. Hydrobiologia, 595: 275-286. 